\title{
Statistical Analysis of the Risk Factors of Children Leukemia Patients
}

\author{
Amna Younas Bhatti, MSc ${ }^{[1]}$, Ahmed Bilal Waqar, MBBS, MPhil, PhD ${ }^{[2]}$ \\ ${ }^{1}$ Department: Department of Radiological Sciences and Medical Imaging, Faculty of Health and Allied Sciences, Imperial College of \\ Business Studies, Lahore
}

${ }^{2}$ Faculty of Health and Allied Sciences, Imperial College of Business Studies, Lahore.

\begin{abstract}
Background: Leukemia is a growing disease. The risk factors such as parental age, cousin marriage, exposure to pesticides and radiation, parental smoking, breastfeeding, and the number of older siblings are suggested as the risk factors for childhood leukemia. Objective: To evaluate the possible risk factors for childhood leukemia, including environmental, parental, genetic and other factors. Methods: The case-control study was conducted from September 2015 to December 2015 in Inmol cancer hospital and children hospital Lahore Pakistan. Case subjects were children aged from 1-14 years and diagnosed with leukemia. Control subjects were children aged from 1-14 years taken from the normal community, and individually matched for age and gender to the case subject group. Patients and parents were interviewed the questions designed in a structured questionnaire. Data was analyzed using Chi-square. Results: Parent's age, cousin marriage, gender of the child, industrial exposure, exposure to radiations, genetic disease, and family history of disease and area of living are the risk factors of childhood leukemia. Conclusion: Cousin marriages, advanced maternal age, parental age, industrial exposure, radiation exposure, area of living and genetic diseases are the risk factors of childhood leukemia.
\end{abstract}

Keywords: Childhood leukemia, risk factors, parental age

\section{Introduction}

Cancer is a large group of almost 100 diseases.Leukemia is a cancer of blood cells. It is the most common malignancy that occurs during childhoodaccounting for $30 \%$ of all cancers diagnosed in children younger than 15 years. Leukemia result from an event in bone marrow cell which gives rise to the immature progeny that lost the capacity to differentiate and thus proliferate in an uncontrolled manner. The incidence rate of childhood leukemia is not known due to the lack of diagnosecorrectly ${ }^{[1]}$. The etiology of the childhood leukemia remains unclear. Epidemiologic studies have examined a number of possible risk factors (e.g., environmental, genetic, or infectious ${ }^{[2]}$. . Any of the bloodforming cells from the bone marrow can turn into a leukemia cell. Leukemia is often described as being either acute (fast growing) or chronic (slow growing). Acute leukemia involvesacute lymphocytic (lymphoblastic) leukemia (ALL) which is the most common type of leukemia that occurs during childhood. This leukemia starts from early forms of lymphocytes in the bone marrow. ALL is most common type of childhood leukemia, develops from early forms of lymphocytes. Acute myelogenous leukemia (AML) is another acute leukemiais also called acute myeloid leukemia, or acute non-lymphocytic leukemia, accounts for most of the remaining cases. AML starts from the myeloid cells that form white blood cells (other than lymphocytes), red blood cells, or platelets. Chronic leukemias are much more common in adults than in children and have slow growth rate than acute leukemiasbut they are also harder to cure. Chronic leukemias are divided into 2 types. Chronic myelogenous leukemia (CML) which rarely occurs in children and its treatment is similar to that used for adults (see for more information "Treatment of children with chronic myelogenous leukemia"). For more detailed information on CML, see Leukemia-- Chronic Myeloid.Chronic lymphocytic leukemia (CLL) is extremely rare in children. For more information on CLL, see
Leukemia--Chronic Lymphocytic.Juvenile myelomonocytic leukemia (JMML) is rare type of leukemia is neither chronic nor acute. It begins from myeloid cells, but it usually doesn't grow as fast as AML or as slow as CML. It occurs most often among young children (under the age 4). Signs and Symptoms for leukemia can include pale skin, fever, cough, easy bruising or bleeding, trouble breathing (from too many white blood cells in the lungs) and an enlarged spleen and lymph nodes. The risk factors for childhood leukemiaare Lifestyle-related risk factors (Such as tobacco use, diet, body weight, and physical activity play a major role in many adult cancers. But these factors usually take many years to influence cancer risk, and they are not thought to play role in childhood cancers, including leukemias), Genetic risk factors (are those that are part of our DNA. They are most often inherited from our parents. While some genetic factors increase the risk of childhood leukemia, most leukemias are not linked to any known genetic causes). Some inherited disorders increase a child's risk of developing leukemia involvesDown syndrome (trisomy 21) and $\mathrm{Li}$ Fraumenisyndrome. Inherited immune system problems (Certain inherited conditions cause children to be born with immune system problems. These include Ataxiatelangiectasia, Wiskott-Aldrich syndrome, Bloom syndrome, Schwachman-Diamond syndrome), Breast feeding (is thought to be among risk factors of childhood leukemia. It plays a protective role and decreases the risk of developing leukemia by $17 \%$ to $19 \%$ even some studies have shown upto $21 \%$ ), Having a brother or sister with leukemia (2 to 4 times' normal) is also one of the risk factors of developing leukemia, but the overall risk is still low. The risk is much higher among identical twins. If one twin develops childhood leukemia, the other twin has about a 1 in 5 chance of getting leukemia as well. Lifestyle-related risk factors (include smoking, being overweight, drinking too much alcohol, and getting too much sun exposure. These types of factors are important in many adult cancers, but they are unlikely to play a role in most childhood leukemia), Environmental risk factors (such as radiation and certain

\section{Volume 5 Issue 7, July 2016}

\section{www.ijsr.net}




\section{International Journal of Science and Research (IJSR) \\ ISSN (Online): 2319-7064 \\ Index Copernicus Value (2013): 6.14 | Impact Factor (2015): 6.391}

chemicals that increase the risk of getting diseases such as leukemia), Radiation exposure (e.gJapanese atomic bomb survivors had a greatly increased risk of developing AML, usually within 6 to 8 years after exposure. If a fetus is exposed to radiation within the first months of development, there may also be an increased risk of childhood leukemia, but the extent of the risk is not clear) The possible risks from fetal or childhood exposures to lower levels of radiation, such as from X-ray tests or CT scans, are not known for sure. Some studies have found a slight increase in risk, while others have found no increased risk to an extent. Any risk increase is likely to be small, but to be safe; most doctors recommend that pregnant women and children not get these tests unless they are absolutely needed, Exposure to chemotherapy and certain other chemicals Chemotherapy and radiation therapy have been very helpful to a lot of people for treatment of many different forms of cancer. These therapies have been linked to second cancer usually leukemia, after several years of treatment. Chemotherapy is stronger risk factor than radiation therapy. Combination of chemotherapy and radiation can significantly increase the risk of leukemia after first cancer. Children and adults treated for other cancers with certain chemotherapy drugs have a higher risk of getting a second cancer, usually AML, later in life. Drugs such as cyclophosphamide, chlorambucil, etoposide, and teniposide have been linked to a higher risk of leukemia. These leukemias usually develop within 5 to 10 years of treatment, and they tend to be hard to treat. Exposure to chemicals such as benzene (a solvent used in the cleaning industry and to manufacture some drugs, plastics, and dyes) may cause acute leukemia in adults and, rarely, in children. Chemical exposure is more strongly linked to an increased risk of AML than to ALL. Several studies have found a possible link between childhood leukemia and household exposure to pesticides, either during pregnancy or early childhood. Some studies have also found a possible increased risk among mothers with workplace exposure to pesticides before birth. However, most of these studies had serious limitations in the way they were done. More research is needed to try to confirm these findings and to provide more specific information about the possible risks.Children who are getting intensive treatment to suppress their immune system (mainly children who have had organ transplants) have an increased risk of lymphoma and ALL.In developing countries, pediatric malignancies account for 4.1 to $12.6 \%$ of all malignant tumors (Abdullah et al 1996). The pattern of childhood tumors is different as compared to the adults, in different geographical areas and ethnic groups, with some known and mostly unknown causative factors (Powell et al 1994). In developing countries lymphoma and leukemia are the most frequent and this has also been reported in different studies of Pakistan (Bhurgri, 2001; Ahmad et al., 1991; Zaidi\&Jaffery, 1977). Leukemia is also reported to be the commonest malignancy in some European studies (Zuccolo et al., 2004; Desandes et al., 2004), but lymphoma is not as common. The signs and symptoms depend on the location of malignancy, abdominal tumors often presenting with pain, vomiting, constipation or intestinal obstruction. Lymphoma usually presents with lymphadenopathy, cervical lymph nodes being the most frequently involved (Ahmed et al., 1993). The behavior of these tumors, of course depends upon the histological type and degree of differentiation
(Shah et al., 2000). Childhood cancer may mimic many other diseases as well.

\section{Methodology}

It was a case control study aimed at investigating the risk factors of childhood leukemia and the quality of life of leukemia patients and of normal healthy persons which were the controls. Socio-demographic status and awareness about disease were also included. Children with leukemia ranges in age between 1-14 years were included in this research. The children less than 1 year or greater than 14 years were included and those which have diagnostic test of leukemia but do not fulfill the diagnostic criteria of leukemia were not included in the study. This case-control study was conducted at two hospitals (children hospital and Inmol cancer hospital) of Lahore Pakistan in the duration of almost four months (September 2015-December 2015). It was a time based study. Data was collected in almost two months from cases and controls. The cases and controls were taken in the ratio 1:1. The number of cases and controls that were included in this study during data collection period were almost 300. Data was collected on a well-structured questionnaire. The questionnaire was interviewed from the individuals that were included in the study (leukemia patients and normal controls). The data was analyzed by using statistical software SPSS version 17.0. All the collected data was coded according to a suitable coding scheme.Pearson Chi-Square test is used to check the goodness of fit, association and homogeneity of the variables in a data set. The $x^{2}$ in this study was used in order to check the association of the selected independent variables with the dependent variable that was the disease leukemia.

\section{Results}

Table: IS0ciodemographic \& Risk factor variables

\begin{tabular}{|c|c|c|c|c|}
\hline Variables & & Case & Control & $\begin{array}{l}\text { Total } \\
\text { \%age }\end{array}$ \\
\hline \multirow{2}{*}{$\begin{array}{l}\text { Gender of } \\
\text { child }\end{array}$} & Male & 107 & 81 & $188(62.7 \%)$ \\
\hline & Female & 43 & 69 & $112(37.3 \%)$ \\
\hline \multirow[t]{3}{*}{ Age of child } & 1-4 year & 29 & 37 & $66(22 \%)$ \\
\hline & 5-9 year & 45 & 44 & $89(29.7 \%)$ \\
\hline & 10-14years & 76 & 69 & $145(48.3 \%)$ \\
\hline \multirow{5}{*}{$\begin{array}{l}\text { Age of } \\
\text { mother }\end{array}$} & 21-30years & 50 & 41 & $91(30.3 \%)$ \\
\hline & 31-40years & 69 & 78 & $147(49.0 \%)$ \\
\hline & 41-50years & 25 & 25 & $50(16.7 \%)$ \\
\hline & 51-60years & 6 & 4 & $10(3.3 \%)$ \\
\hline & 61-70years & 0 & 2 & $2(0.7 \%)$ \\
\hline \multirow[t]{5}{*}{ Age of father } & 21-30years & 20 & 15 & $35(11.7 \%)$ \\
\hline & 31-40years & 60 & 76 & $136(45.3 \%)$ \\
\hline & 41-50years & 57 & 45 & $102(34 \%)$ \\
\hline & 51-60years & 13 & 11 & $24(8.0 \%)$ \\
\hline & 61-70years & 0 & 0 & $0(0.0 \%)$ \\
\hline \multirow{2}{*}{$\begin{array}{l}\text { Mother } \\
\text { smoking }\end{array}$} & No & 149 & 150 & $299(99.7 \%)$ \\
\hline & Yes & 1 & 0 & $1(0.3 \%)$ \\
\hline \multirow{5}{*}{$\begin{array}{l}\text { Education of } \\
\text { mother }\end{array}$} & Illiterate & 52 & 19 & $71(23.7 \%)$ \\
\hline & Primary & 1 & 20 & $21(7 \%)$ \\
\hline & Middle & 33 & 42 & $75(25 \%)$ \\
\hline & Matric-intermediate & 50 & 66 & $116(38.7 \%)$ \\
\hline & $\begin{array}{l}\text { Graduation-post } \\
\text { graduation }\end{array}$ & 14 & 3 & $17(5.7 \%)$ \\
\hline
\end{tabular}


International Journal of Science and Research (IJSR)

ISSN (Online): 2319-7064

Index Copernicus Value (2013): 6.14 | Impact Factor (2015): 6.391

\begin{tabular}{|c|c|c|c|c|}
\hline \multirow{5}{*}{$\begin{array}{c}\text { Education of } \\
\text { father }\end{array}$} & Illiterate & 36 & 20 & $56(18.67 \%)$ \\
\hline & Primary & 3 & 21 & $24(8.0 \%)$ \\
\hline & Middle & 38 & 33 & $71(23.67 \%)$ \\
\hline & Matric-intermediate & 55 & 51 & $106(35.3 \%)$ \\
\hline & $\begin{array}{l}\text { Graduation-post } \\
\text { graduation }\end{array}$ & 18 & 25 & $43(14.3 \%)$ \\
\hline \multirow{5}{*}{$\begin{array}{c}\text { Occupation } \\
\text { of father }\end{array}$} & Laborer & 32 & 7 & $39(13.0 \%)$ \\
\hline & Private job & 21 & 32 & $53(17.67 \%)$ \\
\hline & Govt. job & 13 & 5 & $18(6.0 \%)$ \\
\hline & Businessman & 4 & 31 & $35(11.67 \%)$ \\
\hline & other & 80 & 75 & $155(51.7 \%)$ \\
\hline \multirow{2}{*}{$\begin{array}{c}\text { Occupation } \\
\text { of mother }\end{array}$} & House wife & 139 & 150 & $289(96.3 \%)$ \\
\hline & employee & 11 & 0 & $11(3.7 \%)$ \\
\hline \multirow{3}{*}{$\begin{array}{l}\text { Family } \\
\text { income }\end{array}$} & $<\mathrm{Rs} 20,000$ & 32 & 18 & $50(16.7 \%)$ \\
\hline & Rs20,000-50,000 & 86 & 88 & $174(58.0 \%)$ \\
\hline & $>$ Rs50,000 & 32 & 44 & $76(25.3 \%)$ \\
\hline \multirow{2}{*}{$\begin{array}{c}\text { Area of } \\
\text { living }\end{array}$} & Rural & 75 & 17 & $92(30.7 \%)$ \\
\hline & urban & 75 & 133 & $208(69.3 \%)$ \\
\hline \multirow[t]{4}{*}{ Marriage } & Not cousin married & 43 & 36 & $79(26.3 \%)$ \\
\hline & $1^{\text {st }}$ cousin marriage & 81 & 79 & $160(53.3 \%)$ \\
\hline & $2^{\text {nd }}$ cousin marriage & 12 & 5 & $17(5.7 \%)$ \\
\hline & Other in family & 14 & 30 & $44(14.7 \%)$ \\
\hline \multirow[t]{3}{*}{ Rooms } & 1 room & 33 & 37 & $70(23.3 \%)$ \\
\hline & 2 rooms & 35 & 39 & $74(24.7 \%)$ \\
\hline & $>2$ rooms & 82 & 74 & $156(52.0 \%)$ \\
\hline \multirow[t]{2}{*}{ Breast feed } & N0 & 13 & 18 & $31(10.3 \%)$ \\
\hline & yes & 137 & 132 & $269(89.7 \%)$ \\
\hline \multirow{3}{*}{$\begin{array}{c}\text { Duration of } \\
\text { feeding }\end{array}$} & $\leq 6$ months & 23 & 21 & $44(16.2 \%)$ \\
\hline & 7-12months & 17 & 17 & $34(12.5 \%)$ \\
\hline & $>1$ year & 97 & 96 & $193(71.2 \%)$ \\
\hline \multirow[t]{4}{*}{ Type of milk } & Formula milk & 23 & 20 & $43(60.6 \%)$ \\
\hline & Buffalo milk & 11 & 5 & $16(22.5 \%)$ \\
\hline & Milk pack & 3 & 4 & $7(9.9 \%)$ \\
\hline & other & 0 & 5 & $5(7.0 \%)$ \\
\hline \multirow{5}{*}{$\begin{array}{c}\text { Type of } \\
\text { leukemia }\end{array}$} & No leukemia & 0 & 150 & $150(50 \%)$ \\
\hline & CLL & 3 & 0 & $3(1.0 \%)$ \\
\hline & ALL & 136 & 0 & $136(45.3 \%)$ \\
\hline & CML & 1 & 0 & $1(0.3 \%)$ \\
\hline & AML & 10 & 0 & $10(3.3 \%)$ \\
\hline \multirow{5}{*}{$\begin{array}{c}\text { Exposure to } \\
\text { radiation }\end{array}$} & No exposure & 0 & 124 & $124(41.3 \%)$ \\
\hline & X-rays & 17 & 21 & $38(12.7 \%)$ \\
\hline & CT-scan & 0 & 3 & $3(1.0 \%)$ \\
\hline & MRI & 0 & 2 & $2(0.7 \%)$ \\
\hline & All of three & 133 & 0 & $133(44.3 \%)$ \\
\hline \multirow{2}{*}{$\begin{array}{c}\text { Exposure to } \\
\text { industry }\end{array}$} & No & 85 & 39 & $124(41.3 \%)$ \\
\hline & Yes & 65 & 111 & $176(58.7 \%)$ \\
\hline \multirow{3}{*}{$\begin{array}{l}\text { Physical } \\
\text { activity of } \\
\text { child }\end{array}$} & Regularly & 106 & 135 & $241(80.3 \%)$ \\
\hline & Sometimes & 43 & 14 & $57(19.0 \%)$ \\
\hline & Not at all & 1 & 1 & $2(0.7 \%)$ \\
\hline \multirow{2}{*}{$\begin{array}{l}\text { Genetic } \\
\text { disease }\end{array}$} & No & 95 & 150 & $245(81.7 \%)$ \\
\hline & Yes & 55 & 0 & $55(18.3 \%)$ \\
\hline \multirow{2}{*}{$\begin{array}{c}\text { Family } \\
\text { history of } \\
\text { disease } \\
\end{array}$} & No & 95 & 126 & $221(73.7 \%)$ \\
\hline & Yes & 55 & 24 & $79(26.3 \%)$ \\
\hline & No & 132 & & $132(88.0 \%)$ \\
\hline $\begin{array}{l}\text { cancer } \\
\text { treatment }\end{array}$ & Yes & 18 & & $18(12.0 \%)$ \\
\hline Diagnostic & Bone marrow biopsy & 47 & & $47(31.3 \%)$ \\
\hline test & Complete blood count & 102 & & $102(68.0 \%)$ \\
\hline & \begin{tabular}{|c|}
$\begin{array}{c}\text { Peripheral blood } \\
\text { morphology }\end{array}$ \\
\end{tabular} & 1 & & $1(0.7 \%)$ \\
\hline Cure of child & No & 104 & & $104(69.3)$ \\
\hline & yes & 46 & & $46(30.7 \%)$ \\
\hline Remission & Consolidation therapy & 10 & & $10(22.2 \%)$ \\
\hline therapy & Maintenance therapy & 35 & & $35(77.8 \%)$ \\
\hline
\end{tabular}

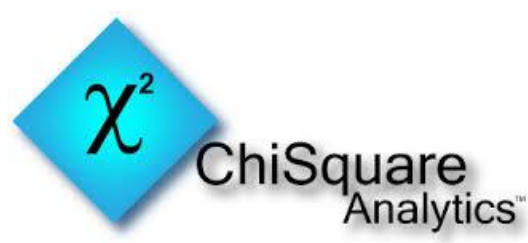

Chi-square test

$$
\chi^{2}=\sum \frac{(O-E)^{2}}{E}
$$

Table III

\begin{tabular}{|c|c|c|c|}
\hline Characteristics & Chi-square & $d f$ & $p$-value \\
\hline Gender of child & 9.631 & 1 & 0.002 \\
\hline Age of child & 1.319 & 2 & 0.517 \\
\hline Age of mother & 40.632 & 4 & 0.014 \\
\hline Age of father & 56.793 & 4 & 0.006 \\
\hline Mother smoking & 1.003 & 1 & 0.317 \\
\hline Education of mother & 42.933 & 4 & 0.000 \\
\hline Education of father & 19.714 & 4 & 0.001 \\
\hline Occupation of father & 42.854 & 4 & 0.000 \\
\hline Occupation of mother & 11.419 & 1 & 0.001 \\
\hline Family income & 5.838 & 2 & 0.050 \\
\hline Area of living & 52.738 & 1 & 0.000 \\
\hline Marriage & 9.346 & 3 & 0.025 \\
\hline Rooms & 0.855 & 2 & 0.652 \\
\hline Breast feed & 0.899 & 1 & 0.343 \\
\hline Duration of feeding & 0.063 & 2 & 0.969 \\
\hline Type of milk & 7.489 & 3 & 0.05 \\
\hline Type of leukemia & 300.00 & 4 & 0.000 \\
\hline Exposure to radiation & 262.421 & 4 & 0.000 \\
\hline Exposure to industry & 29.087 & 1 & 0.000 \\
\hline Physical activity of child & 18.244 & 2 & 0.000 \\
\hline Genetic disease & 67.347 & 1 & 0.000 \\
\hline Family history of disease & 16.513 & 1 & 0.000 \\
\hline
\end{tabular}

A descriptive analysis of socio-demographic characteristics of case-control study subjects showed that out of 150 patients76 children were of age between 10-14 years. The controls were of the same age groups. It has been clearly seen that the occurrence of disease among cases has increased by age. There were 107 males in children having disease leukemia while the females were 43 . It was cleared that the occurrence of disease was more among males than females. Maximum mothers whoseage was between 31-40 years were 69 out of 150 cases and 78 were out of controls. Mean age of mother with standard deviation was $37.88 \pm 7.371$ years.

Maximum of father age was found to be in the range 31-40 years and the frequency was $60,41-50$ years were 57 and among controls were: $21-30$ years $15,31-40$ years $76,41-50$ years 45, 51-60 years 11 . Mean age of father with standard deviation was $41 \pm 8.331$ years respectively. Among mothers of cases, 149 mothers were nonsmokers while only 1 mother smoke. In controls, out of 150 mothers, all 150 mothers were nonsmokers. The trend of mother smoking is much common in western countries while in Pakistan this trend is not common. Smoking of mother is also one of the risks in developing leukemia. Education is the most important tool for assessing the awareness of people regarding diseases, cure and their prevention. In this study of descriptive analysis, the mother's education levels was maximum found to be in between matric-intermediate and they were 50 in

\section{Volume 5 Issue 7, July 2016}




\section{International Journal of Science and Research (IJSR) \\ ISSN (Online): 2319-7064 \\ Index Copernicus Value (2013): 6.14 | Impact Factor (2015): 6.391}

cases and 66from controls, 14 of cases and 3 of controls were having education level between graduation to post graduation.

The education of father among cases and controls showed that maximum education was in range between matricintermediate and was found in 55patient's fathers and 51of normal controls. In occupation of father, 80among cases and 75of control's fathers out of 150 cases and 150 controls who were doing other occupation that includes farming etc.

In studying occupation of mother, it was seen that mostly mothers were house wife in cases and controls while a minority of mothers were employed. Out of 150 case's mothers 139 of mothers were house wife and 11 were employed. Among controls, all 150 (100\%) mothers were house wife and none was employed.

The monthly family income of cases and controls was found maximum in 860 cases and 88 of controls having family income between 20,000 to 50,000 rupees. It was cleared that majority belongs to a mediocre family.

In the analysis of area, it was found that out of 150 cases 75of patients and among 150 controls 17 were belonged to rural areas while 75 of cases and 133 controls were from urban areas. It was cleared that majority of people are urban areas living. It was also seen that out of 150 cases 75 were from rural areas and 75of controls were belonged to urban areas.

The parents having marriages out of family means they were not cousin married were 43 cases and 36were that of controls. The parents which were having first cousin marriage were 81 in cases and 79in controls, 12 of cases and 5 of controls were second cousin married. Only 14of cases and 30 of controls were found to be married with someone in the family. Cousin marriage is found to be the most important risk factor of leukemia.

When type of leukemia was studied, it was found that out of 150 diseased children 3 cases were of Chronic lymphocytic leukemia (CLL), 136children were of acute lymphoblastic leukemia (ALL), chronic myeloid leukemia (CML) was found in 1 case and acute myeloid leukemia in 10children.Acute lymphoblastic leukemia was the most prominent and common type of leukemia among children.

In identifying the risk factors of childhood leukemia, 132 cases were found with no previous cancer treatment while 18 of cases were those which received previous cancer treatment before leukemia. It was studied because previous cancer treatment and radiation exposure plays a significant role in developing disease of blood cancer.

17of patients out of 150 cases were exposed to the X-rays before the diagnosis of disease while 133 of patients were exposed to all of these three radiations X-rays, CT-scan, MRI. Radiation exposure is a strong risk factor of leukemia.

Industrial exposure was another risk factor; it was found 65 cases and 111 of controls were exposed to industries and industrial chemicals. Some were those patients which were living in front of an industry and some were just beside to the industry. In industrial chemicals benzene and pesticides are present which cause blood cancer.

Among case controls, those children which were actively and regularly taking parts in physical activities were 106 in cases and 135 of controls, 48 of cases out of 150 cases and 14of controls out of 150 normal controls that sometimes played and took part in physical activities. It was observed that majority of children with leukemia actively took part in games and activities which was very effective in their early recovery.

In determining diagnostic test which was most common and helpful in diagnosing leukemia, it was found that $47 \mathrm{cases}$ out of 150 which used bone marrow biopsy as a diagnostic test, 102 of cases used complete blood count (CBCs) as diagnostic test for leukemia. The most commonly used test was complete blood count (CBCs) test which showed the number of white blood cells, red blood cells and platelets.

Mostly patients were under treatment. Out of 150 cases, only 45 were receiving post remission therapies while 105 patients were on daily treatment basis. Out of these 45 of patients 10 of patients were receiving consolidation therapy while 35 were receiving maintenance therapy. The most common used remission therapy was maintenance therapy because mostly patients were of (ALL). All these two were the follow up treatment therapies.

In studying the risk factors, genetic disease of the child was also one of risk factors. The cases having genetic disease were 55while 95were those having no genetic disease. All the normal controls were free from the genetic diseases.

\section{Conclusion \& Discussion}

After conducting a study on the bases of data which was collected from cases and controls, a common practice of risk factors was found in children suffering from leukemia. It was known that the number of leukemia patients has been increasing day by day. The results obtained from Chi-Square test. The estimates and classification ability obtained from this technique was approximately equal. The analysis was done by chi-square test. Percentages along with counts of all the characteristics that were included in the study were calculated. Preliminary analysis included all descriptive measures of the data. It was observed that acute lymphoblastic leukemia (ALL) was most common type of leukemia. The type of leukemia was associated with gender. Males were mostly victim of the disease as compared to females which were less frequent. $107(71.3 \%)$ of males and $43(28.7 \%)$ of females were having disease leukemia. 136 (90.7\%) patients were having ALL. Chi-Square analysis was performed in order to check the association and goodness of fit. The risk factors which play their role in inducing leukemia should be control and determined attitudes need to be shown by the government. If this havoc would not be treated with an iron hand, the ratio will keep on mounting and rise to an uncountable level. It was seen that most of the patients were diagnosed in their severe stages, showing that their parents were unaware of the disease at its early stage. The treatment procedure although is quite long, but due to

\section{Volume 5 Issue 7, July 2016 www.ijsr.net}




\section{International Journal of Science and Research (IJSR) \\ ISSN (Online): 2319-7064}

Index Copernicus Value (2013): 6.14 | Impact Factor (2015): 6.391

the socio cultural habits, the cases continued to practice the risk factors, which caused their blood cancer as a result is concerned. Therefore, Strong steps are needed to be taken to amend these pollution causing and life staking problems that such cases will be minimized in near future. Most of the patients were having a family history of disease which is also one of the risk factors. The disease was among mostly the children of cousin married parents. There should be DNA test of the couple before they get marry. The rate of leukemia was high in children of those parents whose age was high. Risk of developing non-communicable diseases like blood cancer and many others increases with age.

\section{References}

[1] SIOP-ICCCPO. Global childhood cancer organizations launch early detection campaign to save thousands of children's lives. [Cited 2012 May 20]; Available from: http://siop-asia.com/en/news-letters/41-siop-icccpopressrelease-2012-02-15.html

[2] Belson M, Kingsley B, Holmes A. Risk factors for acute leukemia in children: a review. Environ Health Perspect. 2007;115:138-45.

[3] Riley PA, Parasakthi N, Abdullah WA. Plesiomonasshigelloides bacteremia in a child with leukemia.Clin Infect Dis.1996 Jul;23(1):206-7.

[4] Alderton LE, Spector LG, Blair CK, et al. Child and maternal household chemical exposure and risk of acute leukemia in Down's syndrome: a report from the Children's Oncology Group. Am J Epidemiol. 2006; 164:212-221.

[5] Atta-ur-Rehman Khan, Moeen-ul-Haq Sheikh, KiranIntekhab. Weight for age has prognostic significance in children with acute lymphoblastic leukemia (ALL). Pak J Med Sci 2006 Vol. 22 No. 2.

[6] Marin. Lopez, Lobato, Mendizabol, Ruiz, Arguelles. Malnutrition as an adverse prognostic factor in the response to treatment and survival of patients with acute lymphoblastic Leukemia at the usual risk. Gac Med Mex. 1991; 127(2): 125-32.

[7] Zuccolo L, Pastore G, Maule M, et al. Time trends of childhood cancer mortality rates: a report from the Childhood Cancer Registry of Piedmont, Italy, 19711998.

[8] Pediatr Blood Cancer. 2004 Dec;43(7):788-91.

Volume 5 Issue 7, July 2016 www.ijsr.net 